Nouveaux visages de l'anglais de spécialité : objectifs, domaines, approches et outils de demain

\title{
ESP in Spain: Goals, achievements and prospects
}

\section{Guadalupe Aguado de Cea and Alejandro Curado Fuentes}

\section{(2) OpenEdition \\ Journals}

Electronic version

URL: http://journals.openedition.org/asp/3136

DOI: $10.4000 /$ asp.3136

ISSN: 2108-6354

Publisher

Groupe d'étude et de recherche en anglais de spécialité

\section{Printed version}

Date of publication: 15 November 2012

Number of pages: 91-107

ISSN: 1246-8185

\section{Electronic reference}

Guadalupe Aguado de Cea and Alejandro Curado Fuentes, «ESP in Spain: Goals, achievements and prospects », ASp [Online], 62 | 2012, Online since 07 October 2014, connection on 03 November 2020 URL : http://journals.openedition.org/asp/3136 ; DOI : https://doi.org/10.4000/asp.3136

This text was automatically generated on 3 November 2020

Tous droits réservés 


\title{
ESP in Spain: Goals, achievements and prospects
}

\author{
Guadalupe Aguado de Cea and Alejandro Curado Fuentes
}

\section{Introduction}

1 English for Specific Purposes (ESP) studies have truly soared institutionally in Spain since the foundation of AELFE, the Association of Languages for Specific Purposes, in 1992. ${ }^{1}$ This Association was founded in Madrid at the time, but a previous decade of growing interest and approaches in English for academic and professional purposes had set the scene for the advent of significant ESP developments. The shift that a growing number of faculties and researchers made from literature studies to applied linguistics also contributed to the emerging new context in many universities. In the teaching of English in higher education, this change was especially visible in business and scientific-technical English. In translation studies, the focus on specialised terminology also influenced the spread of ESP in Spain (e.g., bilingual business and law dictionaries).

2 In the 1990s, AELFE was a Spanish association that included cooperation with Portuguese faculty by holding an annual Luso-Hispano conference. The chief motivation for the creation of AELFE was the support of languages for specific purposes in general, but with more emphasis on ESP because it was in higher demand at this level in Spain and Portugal. Becoming a member of AELFE and attending the conferences certainly built up the academic status of faculties at a time when traditional English studies scholars looked down on applied linguistics and ESP.

In 2001, AELFE turned European as more members from other countries in Europe entered the association (e.g., Germany, Italy, Romania, Bulgaria). Since then, the interest in ESP has expanded and consolidated not only with more research and conferences held in Spain and other countries, but with more university English departments coming into their own and embracing applied linguistics. 
In this paper, the chief aim is to provide a detailed account of how ESP has evolved in Spain over the past twenty years. We decided to focus on Spain to provide a description of ESP as emerging, developing and expanding in conjunction with AELFE's own evolution. The case study of Spain may also be taken as reference and contrast for other works. Our paper is divided into two main sections: Past and present situations of ESP in Spain so as to provide a complete overview of the domain based on achievements and events. The main aspects related to such developments are summarised in the following points: first, the administrative situation that sets out the basis for the creation of AELFE, and the changes at university level that have influenced the present situation; secondly, educational aspects to which ESP teachers have contributed as well as the teaching methodologies developed under the socio-political situations affecting past, present and future prospects; and thirdly, research lines and their evolution over such periods. Finally, we propose conclusive remarks on the likely shape of things to come in ESP over the next few years.

\section{The past of ESP in Spain: 1980-2002}

5 The first paper published in Spain on ESP appeared in 1983 (Monroy 1983), which implies that active work in teaching and learning had already been taking place. Nonetheless, as far back as the 18th and 19th centuries, French and English were already studied in some military institutions and engineering schools, such as mining engineering. This interest in languages extended to other professions that realised the importance of international communications in trade and commerce. In the so-called Commerce Schools students had to learn two or more languages, Arabic included, as they were expected to operate in international business contexts. Surprisingly, as time went by, the time assigned to languages and communication skills was drastically reduced in these schools, although international relations developed considerably. All in all, advances were made in certain scientific areas while, in others, language training declined.

\subsection{Administrative perspectives}

6 ESP curricula grew in Spanish universities during the early 1980s because of a favourable administrative direction under the University Reform Law (Ley de Reforma Universitaria), passed in 1984. This law formed the basis for the creation of university departments that could prioritise and distribute their teaching load over all university degrees. English became the main foreign language in various engineering majors and other non-humanities studies, while French and other languages almost vanished from curricula. The ESP instructors assigned to such courses were mostly assistants on a non-tenured basis and had little relationship, if any, with other ESP colleagues in other schools; in this sense, the ESP teacher tended to function alone in his/her own workplace.

7 Two main administrative scenarios emerged thereafter. In the first situation, English faculty, mainly teaching in scientific-technical degrees, embraced linguistics as their specialisation, and together with some other language teachers in French and German, formed Applied Linguistics Departments (e.g., Madrid's Polytechnic University). This situation was favourable to ESP. The other situation has been much less supportive, and 
actually comprises the majority of cases: The inclusion of both general English and ESP teaching under the same departmental umbrella, mostly headed by professors coming from the literature research area and working in humanities colleges. The tendency was to consider English courses for majors other than philology studies apart from the core English studies, with a consequent lower academic status yielded to ESP practitioners, who would not be provided with tenure tracks unless they made the leap from their line of work into more traditional philology.

of such initial difficulties, the 1984 Law enabled the gradual branching of English teaching positions in all the colleges, and more and more tenured positions became available, paving the way for subsequent promotion in ESP under the same conditions as those for general English and literature academics. The new situation led to great strengthening in the field in terms of both teaching and research. ESP instructors thus began to design formal courses and syllabi, as well as to outline research for future promotion.

Over a fifteen-year period, until the late 1990s, many teachers obtained permanent positions in state universities, as the financial situation in the country was encouraging and the number of students increased. A moderately larger number of teachers in private universities also profited from the implementation of the 1984 Law. However, this new situation was not without barriers. Piqué and Viera (1997) perceived that some administrators and university officials questioned and even looked down on ESP courses at Spanish university centres. The burden that ESP practitioners, with or without tenured positions, had to bear came in the form of both academic and administrative under-recognition. Not only did the university management fail to understand the teaching of ESP, but also colleagues and researchers in English philology and scientific-technical degrees contributed to this depreciating view. Some examples at the time ranged from overcrowding in ESP classes as though these could be taught like lectures, to underestimating the nature of research that ESP learners could do within technical majors. Needless to say, the supervision of PhD theses related to ESP and applied linguistics within traditional English Departments was no easy task. Still, the ESP practitioner never relented and kept a steady pace.

It is no surprise that many ESP professionals, sharing such difficulties in their respective academic settings, decided to join efforts by becoming associated nationwide in 1992, after they had already proposed such a collective undertaking, a few years earlier, in the Spanish Association of Applied Linguistics (AESLA 1986). Because the Polytechnic University in Madrid had the largest number of ESP instructors at the time (up to 60 in 19 different engineering schools), this institution became the management headquarters for AELFE. Two main enclaves for early academic recognition of ESP were also the Alcalá de Henares conferences (1990-1998) and the Congreso luso-español de lenguas aplicadas a las ciencias in Evora (Portugal) in 1993.

11 Even though Johns and Dudley-Evans (1991) assured at such an early date that ESP teachers in English-speaking countries had the same career opportunities as any other EFL peers, for Spain, the equal terms took somewhat longer to materialise and, at any rate, the claim was especially less valid as regards full professorships, where traditional English philology studies still prevail today. In the hierarchical scale, ESP has unfortunately lagged behind. 


\subsection{Teaching conditions and methods} Spain with severe headwinds since, as we mentioned before, most teachers lacked tenured positions in a world of general English and literature jobs. Some widespread adverse factors in most universities at the time were: Overcrowded classrooms, mixed abilities in the same courses, reduced programming for ESP courses in the degrees, inconvenient and overlapping hours assigned in schedules, lack of ESP experience and training, lack of suitable materials, inadequate understanding of ESP on the part of fellow specialists and administrators, large diversity of disciplines for ESP (from economics to aeronautical engineering), inexistence of ESP studies for philology students, etc.

It is then no wonder that the initial course syllabi and contents were mainly based on commonsense grounding and driven by students' needs. Some courses integrated register and genre studies, based on early work by Halliday, McIntosh and Strevens (1964), Herbert (1965), and Ewer and Hughes-Davies (1972), among many. Works that were published in the 1980s served as updated reference for ESP and EAP development (e.g., Robinson 1980; Trimble 1985; Davies 1988...). Such authors kept the ESP practitioner in good company, and the study of genres and needs analyses could partly give solutions, at least for the management of large heterogeneous groups. The design of courses was prioritised according to specific tasks aimed at meeting learning demands (e.g., Munby 1978; Nunan 1989). Emphasis was also placed, in many cases, on specific terminology and translation, though translation schools went their own way as part of philological studies, outside the emerging ESP area.

Despite this gradually growing methodological base for ESP teaching, the number of specialised course books published was neither large nor diverse. The two main reasons may have been first that a great deal of effort was needed to write a good manual for such large and diverse groups of students, and secondly neither the economic benefits nor the academic recognition could motivate teachers to invest a lot of time and effort in likely underrated didactic work. The result was that most ESP practitioners saved their time and research for $\mathrm{PhD}$ theses, which would lead them to expand their careers and guarantee tenure tracks. The fact that many ESP teachers began to present their work in national, international conferences and seminars led to shared interests for the dissemination of relevant work.

\subsection{Research dissemination}

The past of ESP research in Spain may be analysed from different angles, depending on the types of outlets where such works appeared. Most of the authors who published at this early period presented their papers in conferences, where many doctoral theses found transmission channels. As a reference, we may mention the number of dissertations in the applied linguistics area (400) archived in the Spanish TESEO (Thesis) Database from 1976 to 1996 (Codina, Fortanet \& Otal 1996), which doubled over the next decade. The domain was definitely well established by the late 1990s.

For a quantitative view of this process, we have selected three resources that may illustrate the main ESP research stage until the early 2000s: first, Rosario Bueno's analysis of ESP publications in Spain from 1985 to 2002 (Bueno Lajusticia 2003); then, 
the Languages for Specific Purposes conferences held in Canet de Mar (Barcelona) from 1997 to 2001, and finally the Ibérica journal papers from 1996 to 2002.

17 According to Bueno (2003), a first major event that took place in the 80s was the Association of Applied Linguistics (AESLA) conference held in Pamplona in 1988, which led to the publication of 25 papers on ESP. As years passed, this number grew exponentially, and 1997 represented the peak period for ESP dissemination in Spain, with more than 330 papers published in six different Languages for Specific Purposes conferences held in Spain and Portugal that year. The outlets for these papers were the proceedings for the conferences, initially conceived as collected issues of all the presentations transferred to paper-based form. As technological and editorial progress was made, such collections became edited monographs in either paper or electronic forms that provided readers with selected and improved versions. One of the motivations for this change, apart from the obvious saving and academic projection reasons, was the lower rating that the early conference proceedings received for research merits, especially when such a consideration had to compete with the higher recognition given to locally published literature proceedings.

For the second reference, the Canet de Mar conferences, five years are observed (1997-2001). The other major event, the Alcalá de Henares conference (1990-1998) is not considered because it was held, irregularly, every two or three years. The number of papers in all the Canet de Mar conferences ranged between 51 and 80, with 1999 as the peak year with 80 papers. The number of papers in English increased from 19 in the first year to 37 in 2001, whereas the number of papers in Spanish decreased slightly, from 25 to 22. As this conference was held in Catalonia, there were also works in Catalan, 18 over the five years that the conference was held. It seems then that research dissemination in these Catalan conferences paralleled that same interest revealed in other Spanish/Portuguese conferences, with major topics and approaches discussed in different languages.

The Ibérica journal is also a valuable source to describe the evolution of ESP research. We can differentiate two phases in this journal: first of all, a dissemination period until 2002 with its early research work, comprising a first issue in 1996 and then three volumes between 1999 and 2002. Then, a more productive phase (2003-2012) in terms of both quantity and diversity of topics investigated along sixteen volumes (see Section 2.3).

20 In the first period until 2002 there were 28 papers. Rosario Bueno's (2003) thematic categories can be used for the organisation of the papers under ESP headings, e.g., those papers that focused on ESP teaching are listed under the more general title of language learning and teaching. We should also underline a new item, cognitivism and metaphors, because some papers dealt with metaphors in specialised discourse, a line of work opening in Ibérica 1999. Another group is lexicology/terminology, but in this case, papers about specialised translation are added, as they also focused on lexical transfer to other languages. During that period, the papers were not long (about 3,000 words or even less), which, compared to TESOL Quarterly for instance with an average number of 5,000 words, is fairly short. The papers also tended to display results and findings without much backing from empirical data.

21 The main difficulty in the approach to this material lies in the interpretation of keywords and titles to categorise the papers by listed topic. Especially in the use of keywords, some papers do not hint at any clear-cut line of work, and they may be 
assigned to more than one topic group. As a result, the topics are classified for this first period of Ibérica until 2002 as follows:

- Needs analysis and related subjects, such as materials selection;

- Course design;

- Text analysis: discourse, register, genre. We include here both written and oral discourse.

- LSP teaching and learning. Skills methodology (reading, writing, listening and speaking);

- Cognitive approach to LSP, metaphors in specialized texts;

- Lexicology, lexicography and translation. Technical vocabulary;

- Corpus linguistics and contrastive analysis;

- New technologies. Use of audiovisual aids in ESP classes.

In Figure 1, we compare the thematic panels for the 28 papers from Ibérica (1996-2002) with Bueno's (2003) classification of the 1,422 papers published by ESP teachers in different conference publications.

Figure 1. Percentages of papers published from 1985 to 2002 (Bueno 2003) vs. Ibérica (1996-2002)

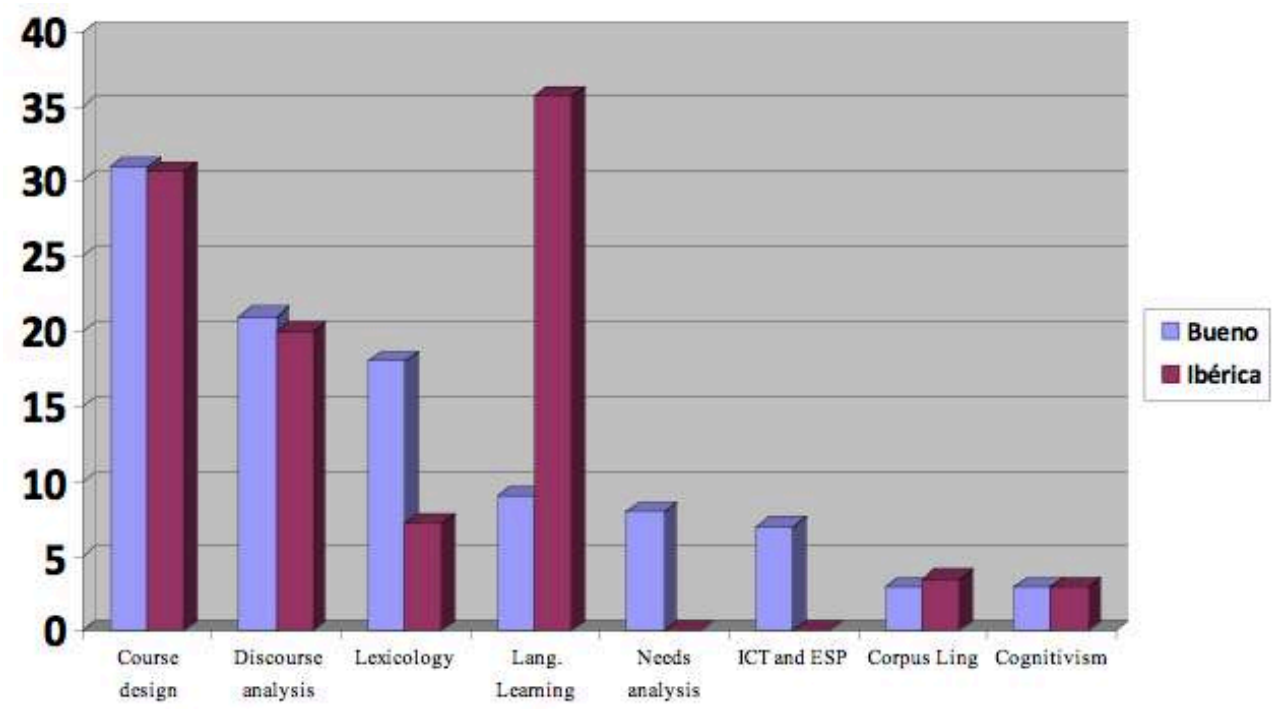

The contrastive view reveals a significant larger proportion of papers published in the journal on the subject of ESP learning/teaching. In turn, the works collected in Bueno (2003) range across a wider set of topics, with higher percentages found in the other areas, except for discourse analysis and course design, where both references have similar quotas, and for corpus linguistics and cognitive linguistics, where both sources have few representatives.

Early authors in Ibérica may have thus inclined more towards concerns related to research for teaching aims. Most writers were ESP practitioners in Spanish universities (79.5 percent), and this may have strongly supported that approach. In turn, foreign authors subscribed to the genre/discourse analysis scope (e.g., Salager-Meyer 1999; Bhatia 2002). The absence of approaches to ICT (Information and Communication Technologies) and needs analysis in ESP at that time may have resulted from such priorities. Alternatively, a diversity of research topics encompassed in the various conference proceedings in the 1990s was not transferred to the journal, where editorial lines may have favoured research in the direction of the major international references followed at the time (e.g., Jordan 1997; Dudley-Evans \& St John 1998, etc.). 


\section{The present of ESP. 2003-2012}

We decided to choose 2003 as the pivotal year of ESP in Spain as it opened in sharp contrast with the period of initial developments. This was also the year when AELFE expanded in Europe but retained its management in Spain, and the Ibérica journal was indexed in international databases. A first highly successful international AELFE conference was held in Madrid in 2002, with more than 150 papers from different countries presented and selected for publication. At university level, the Bologna treaty had unveiled new challenges for the undertaking of ESP projects in technical and business degrees, where the focus on communicative competences was underlined. A more mature period then unfolded, as more tenured ESP teachers were now facing these new developments with the benefit of experience. We can re-examine the three sides from the past in this present phase: Administration, teaching and research.

\subsection{Administrative perspectives}

These last ten years may be regarded as a maturity age for ESP in Spain in spite of the persistent state of administrative instability in universities. When we say that it represented a period of maturity, we mean that the situation and conditions for ESP teachers had changed for the better. Many ESP teachers had completed their theses and obtained tenured positions. For their teaching and research projects, more relationships also emerged with well-known ESP practitioners from overseas universities.

However, there was a general concern as to how the implementation of the Bologna process might affect both teachers and courses in the new technical degrees. By 1999, twenty-nine countries had signed the Bologna Declaration. One of its objectives was to offer compatible degrees in all the signing countries. And yet, the declared consensus hid underlying tensions concerning the implementation of policies, and after all, there did not seem to be an agreement on the duration of the degree cycles. ${ }^{2}$

In Spain, most degrees (e.g., engineering and business) were structured as four-year Bachelors followed by one-year Masters. The distribution of content subjects was also done according to academic and professional competencies, where an intermediate level for a foreign language (especially English) became a requirement. The paradox, however, was that some executive committees in charge of the curriculum designs decided to exclude ESP as an obligatory subject in some studies (e.g., engineering), while other academic designers seized the opportunity to make ESP compulsory in certain fields, though not in all universities (e.g., medicine, physical education, nursing, etc.).

The university context during the 2000s was also influenced by certain socio-political factors that have become even more acute in the 2010s: first the low birth rate of Spain in the 1980s eventually led to a lower number of students; secondly, the regional and local administrations' aims and efforts at universities during the 1980s and 90s for the creation of new degrees resulted in the existence of unrequired studies (initially set up without a clear needs analysis that might have predicted, for example, the low number of potential students enrolling, and the professional demands in those regions); and thirdly the exponential growth of universities in each region suffered dramatically 
from drastic budget cuts with which to operate, especially after the economic crisis of 2008.

The threat of depopulating universities has become a relevant factor over this past decade, and administrations had to adapt to the hard facts of life. In the Humanities, traditional philology studies have opened up towards a greater deal of interdisciplinarity in their content subjects and approaches. This opportunity has favoured many ESP teachers, as they have been able to incorporate more easily into the new Humanities degrees (e.g., teaching EAP and/or working with content teachers in double degrees). Another advantage is the integration of subjects taught in English, also seeking ESP experts' advice, planning and performance.

Still, although either parts of the subjects or the whole syllabi are in English, the fact is that this flexibility is not transmitted to the administrative side in terms of certified academic loads for ESP teachers, thus they still receive less recognition for their work. ${ }^{3}$ Therefore, many good-will efforts have turned into disenchanted would-bes, and the positive merging of language and content has not materialised in many cases. In addition, many content teachers lack the proper training to teach in English.

\subsection{Teaching conditions and methods}

ESP teaching and methodology have profited from some of these academic and sociological factors. First, as the level of English that students have when entering ESP courses has somewhat risen (i.e., roughly from A1 to A2/B1 levels), approaches have slightly changed towards more specialised training. An example is the general shift from grammar-based/functional-notional syllabi towards academic /professional communication skills and genre use, e.g., emphasizing both writing and oral presentation abilities in fields such as tourism, business and administration, medicine, law, etc.

Secondly, groups have become more manageable in many cases, as types other than the lecture/large grouphave been assigned to ESP courses, enabling the division of groups into smaller subgroups. The creation of specialised seminars has also been facilitated as a result, and ESP practitioners can then receive the proper administrative recognition for their teaching loads. A disadvantage, however, is that while teachers have to give more class hours in both large and divided groups, the students have fewer of them because they receive one or two in the general group, and only one more in their respective small groups.

Thirdly, ESP practitioners can find easier niches in interdisciplinary doctoral and Master programs, where their knowledge of applied linguistics and languages for special purposes conveniently suits new models of teaching and training. One example is the Master for Secondary Education, where subjects that ESP learners often know from research (e.g., corpus linguistics, ICTs, cognitivism...) are required. Other examples are the Valencia Polytechnic University and Jaume I University, which have set up successful ESP Masters aimed at engineering and business majors.

\subsection{Research dissemination}

As in the past stage, we paid attention to the main ESP journal in Spain, Ibérica,for the classification of content and topics according to keywords and titles. The extended 
period analysed (2003-2012) does in fact present a clear evolution of concerns, topics and research lines. Other publications, such as conference proceedings and/or monographs produced as a result of paper selections, are not examined. The reason is that we think that Ibérica alone can provide a consolidated view of quality ESP research in Spain in the present period because of its growing academic authority and status in Applied Linguistics and ESP. Since 2010, the journal has been included in the JCR, with only two years of evaluation, and its impact factor (ISI web of knowledge) mirrors its academic and international credit. ${ }^{4}$

To give a better idea of this evolution in the journal, we consider four main parameters:

- Number of articles in English and Spanish,

- Evolution of topics according to the keywords provided,

- Authorship: Spanish universities vs. other universities,

- Number of authors in each article.

In the past issues (1996-2002), there were 28 articles, 16 written in English (57.1\%) and 12 in Spanish (42.8\%). In the current period, of a total of 125 contributions, 96 have been published in English (76.8\%), 27 in Spanish (21.6\%), and 2 in French (1.6\%). English has thus been prioritised as the journal has gained prestige in the applied linguistics field. Since the Fall volume of 2010, in fact, all authors but one have chosen to disseminate their work in English.

In terms of the research topics and approaches, Figure 2 provides a contrastive view of Ibérica articles published over the last ten years versus the percentages from Figure 1 (1996-2002). Major changes include a greater amount of papers dealing with genre and discourse in specialised fields, but a more reduced focus on teaching methods. Also, the tendency has been stronger for the study of ESP in conjunction with corpus linguistics, cognitive methods, and ICTs, whereas interest in course design has decreased to one third.

Figure 2. Percentages of papers published in Ibérica (2003-2012) vs. Ibérica (1996-2002)

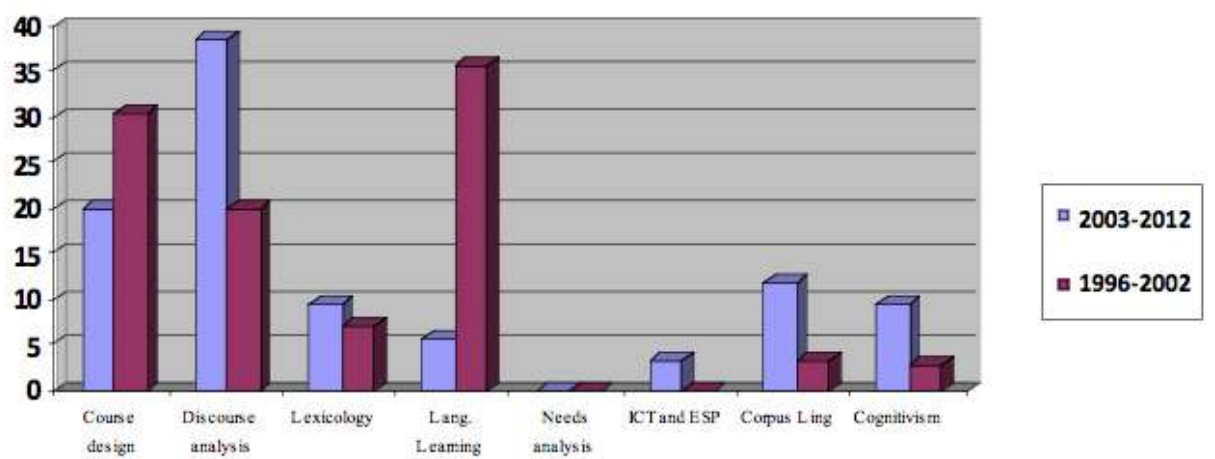

As regards the academic backgrounds of the authors (i.e., the university centres where they work), the percentages rose for international scholars from 20.5 in the past to 30.4 in the present. The Spanish authors (69.6\%) still form the majority but, especially in the last three years, more foreign researchers have become interested in the journal - in keeping with the journal's rising prestige.

Figure 3 presents a comparison between the range of research topics written by foreign scholars and those by authors from Spain. 
Figure 3. Number of research articles in Ibérica (2003-2012) on the different topics by countries of origin

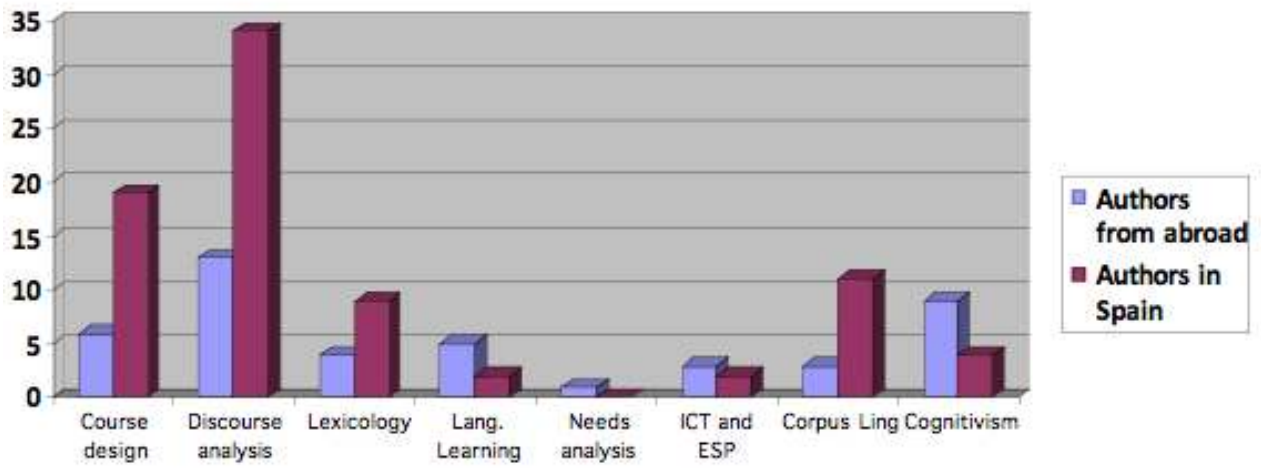

41 Most authors from Spain and abroad decided to focus on Discourse/genre studies, but some significant differences appear: In the topic of Language learning and teaching, the proportion of international writers is higher, and in Cognitive linguistics/Metaphors, more foreign authors are published (especially in two special issues, Ibérica 7 and 17). Also, in a special issue dedicated to ICT and ESP, three authors are from foreign universities, and two from Spain. In the other research areas, more Spanish authors appear, especially in Course Design and Corpus Linguistics, while in Needs Analysis, only one article is found, written by an Argentinian author (Martínez 2011).

In Figure 4, the topics presented by two or more authors are correlated with those authors' academic backgrounds. This information may be useful to observe the topics where joint efforts are salient, and to check the academic contexts where these groupbased research projects are produced. The number of papers in each thematic category is divided into Spanish origin (SP), international background (INT), and mixed groups (if foreign and Spanish authors co-wrote the article (MIX).

Figure 4. Number of papers with two or more authors in the different topics and according to academic backgrounds

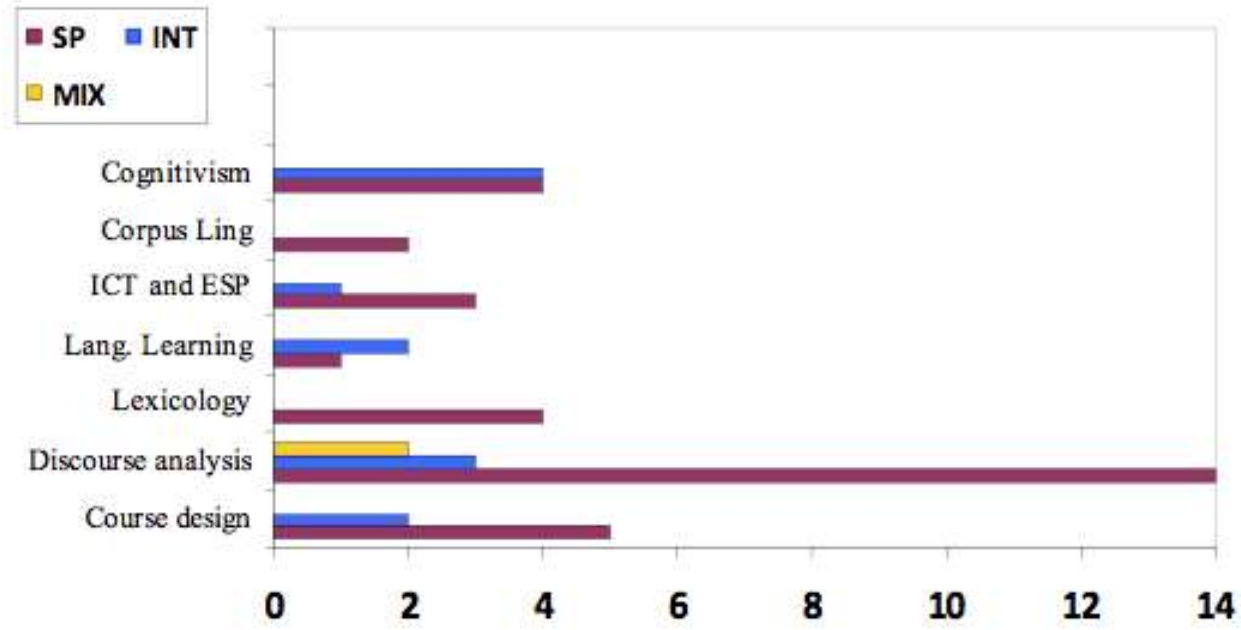

Discourse/genre-based research presents the largest number of co-authored papers from Spanish universities because there are more papers in this area, as examined 
above. Proportionally, however, the highest percentage of papers with more than one author is found in ICT (80\%), with more authors from Spain, followed by Cognitive Linguistics (61.5\%), with the same number of authors from Spanish universities as from foreign universities. In contrast, Corpus Linguistics presents the lowest number of multiple-authored papers (13.3\%).

All in all, the percentage of co-authored papers is 37.6 , and $28 \%$ corresponds to Spanish researchers, a figure which, compared to the co-authored papers from Ibérica in previous years (1996-2002), has increased by $25.3 \%$. There were also no foreign nor mixed groups of authors in the previous period of Ibérica research dissemination. This presence in recent issues is a direct evidence of the journal's current achievements in the international sphere, as well as a result of the international presence of many Spanish scholars in different joint projects.

\section{Conclusions and the future of ESP in Spain}

We may conclude that ESP practitioners in Spain have, indeed, come to maturity over the years. This process has been difficult at times, especially in the administrative side, but several institutional and curricular barriers have gradually fallen. As more and more ESP faculty members received their tenured positions, the process towards teaching and research consolidation strengthened, although full professors in ESP are still rarities relative to other academic ranks.

ESP teachers have also become more knowledgeable about pivotal procedures and approaches to specialties and content expertise. The new Bologna degrees have somehow benefited this specific focus by validating smaller groups for work (e.g., seminars, specialised courses, research tutorials...). The opening of administrative possibilities to account for forms of teaching other than the traditional lecture type can work in favour of ESP developments.

Although teachers seem to agree about positive effects, the European degree system implies some disadvantages too. One is the consequent staff reduction (or no creation of new positions) because of the redistribution of teaching loads; some degrees do offer ESP in the curriculum, but others have omitted them. The effect in many cases is also the increase in course credits (adding small groups and large classes). Some English departments complain about staff shortage, but, because of the economic crisis, no new positions are provided even if the number of students is gradually increasing. What is more, the current trend is to eliminate certain degrees in certain universities or, as a lesser evil, to offer interuniversity degrees. This phenomenon equally affects the possibility to create more teaching positions.

The B1/B2 level requirement for English in many degrees and masters causes many new engineers and business graduates to lack the necessary language skills. The paradox arises in many universities: To comply with the Bologna treaty demands, students are expected to have good across-the-curriculum competencies (e.g., computer skills and foreign language command), but the degree or masters courses do not provide them with the opportunities for such training. Language institutes are thus being re-activated, where courses are offered to cater for such requirements. Needless to say, the courses are on general English, thereby missing the content and practice for future professional use and specialisation. 
The need for ESP development is felt by both teachers and students, but unfortunately little action is being taken in Spanish universities today. Seminars and specialty courses dealing with ESP practice usually focus on EAP (e.g., for research purposes, conference presentations, etc.). In this sense, the approach has evolved positively, as there is a greater general awareness about the importance of non-native internationalisation for ESP. This mentality mainly derives from more participation in research groups that undertake projects abroad.

The present and immediate future of ESP in Spain lies in publications, conferences, projects, and internationalisation. Just taking a look at Iberica's own evolution, we can see that the range of topics has been consistent, and new lines have been emphasized and strengthened with a wider diversity of approaches and backgrounds being offered. Some subjects for interdisciplinary work emerge and evolve, such as research on ICT and genre analysis, or metaphors and specific discourse. More specialised investigation also ensues, e.g., Cognitive Linguistics, or Academic English parallel language. Ibérica thus continues to seek special contributions from experts worldwide on a regular basis.

1 In agreement with Upton (2012), who has reviewed the past fifty years of LSP, the importance given to English as a lingua franca in university settings clearly connects with the ESP practitioners' own interests and foci. This present and future reality is fruitful for careful ESP analysis and research, while consistent emphasis should also be placed on other areas, e.g., on ESP teaching methods and needs analysis so that, for instance, more quality material writing is done according to students' demands in and outside the academic context.

The research base is crucial to lengthen the consolidated work with ESP at universities. Ibérica is a good example to show the exponential quality increase for ESP research, extensive to future publications. ${ }^{5}$ The connection of ESP investigations and interdisciplinary developments can be a strong support. For example, groups who analyse inter-relations among language, discourse, and culture usually have to deal with ESP in some form or other, and thus, multidisciplinary research may progress. One example is that, for Ibérica (No. 26, Fall of 2013), works on intercultural communication in the business context are sought. This is a growing area of interest for the study of specific discourses according to variables other than linguistic, e.g., socio-cultural, ideological, semiotic, etc., where combining different fields of research is needed and can serve as useful reference for other projects.

In relation to future investigations that aim to go further into ESP instruction, we agree with Bhatia (2011) about the need to explore ESP contexts outside the EAP settings, e.g., for the requirements of the workplace. ESP in the classroom must connect more directly and strongly with the world that students will encounter after they graduate. In Spain, the need is even more acute, as learners enter universities with low language commands, but are expected to master specific written and spoken communication skills in a short time span. Thus, as they leave college and apply for jobs, their English may not be effective enough.

54 Working with content teachers is also needed in the future. This collaboration includes programming ESP modules in degree and master courses for the linguistic and textual/ inter-textual content, and for the provision of adequate reasoning mechanisms that help learners to understand specialised discourse (cf. Paltridge 2009). This integration must still advance, since, as Fortanet and Räisänen (2008) explain, the ESP teacher still deserves much academic respect and recognition from fellow content teachers at 
university centres where the value of effective ESP training is misunderstood and/or ignored.

Overall, we agree with Upton (2012) on the evolvement and expansion of the ESP field. This is a reality in Spain too:

Our understanding of what students' needs are has evolved and expanded; how we analyze, describe and teach language is much richer; and our view of the contexts and purposes of language is much more complex. We have moved from prioritizing "words and structures", to prioritizing "texts and purposes", to prioritizing "learners and genres", and are now more concerned with "contexts and interactions". (Upton 2012: 26)

The overall shift at university is crucial for ESP: to go from traditional input-driven and theory-focused teaching to a focus on the learners and the learning outcomes and objectives of that being taught. The adaptation to Bologna should be of the greatest importance in that respect. However, as explained, the ideal setting for the ESP practitioner where the Spanish and international academic community may blend easily and practically is still far from materialising, as both students and faculty tend to lack the necessary communicative skills and, what is more important, training facilities. Nonetheless, some positive experiences in the form of specialised courses and Masters have started, setting a good example for others to follow, especially if these undertakings finally manage to connect with the administration policies.

The new concepts expanding and interweaving in the education arena, i.e., life-long learning, learning-to-learn, autonomous learning, language competence for employability across national borders and so forth, are significant factors in the ESP world. If they materialize successfully, much will have been accomplished. Such factors are being increasingly explored by research groups from Spain in conjunction with others abroad. The large numbers of quality projects and publications are a direct reflection of these efforts. By effectively combining academic and professional work, we believe that the improvement of ESP in Spain can come from its merging with other research areas. This development can lead to more varied and interesting projects over the next few years.

We would like to thank Ana Bocanegra, Editor of Ibérica, for providing us with the information about the journal. We are also grateful to Juan Gabriel Martínez for his help in preparing the graphic material of all the journals. We would also like to thank the GERAS association as well, and in particular Shaeda Isani, for their kind invitation and hospitality at the 2012 Conference held in Grenoble.

\section{BIBLIOGRAPHY}

AESLA. 1986. IV Congreso de AESLA. Córdoba: Universidad de Córdoba.

Belcher, Diane. 2009. "What ESP is and can be: an introduction”. In Belcher D. (ed.), English for Specific Purposes in Theory and Practice. Ann Arbor: University of Michigan Press, 1-20. 
Bhatia, Vijay K. 2002. “Applied genre analysis: a multi-perspective model”. Ibérica 4, 3-19.

Bhatia, Vijay K. 2011. "Critical genre perspectives in ESP: Bridging the gap between the classroom and the workplace". In Proceedings of the 2011 International Conference and Workshop on English for Specific Purposes. Taichung, Taiwan: Crane Publishing Co, 1-3.

Bueno Lajusticia, Ma Rosario. 2003. Lenguas para fines específicos en España a través de sus publicaciones (1985-2002). Madrid: Proyecto Corydon.

Codina, Victoria, Inmaculada Fortanet and José L. Otal (eds.). 1996. Estudios de Lingüística Aplicada. Castelló de la Plana: Publicaciones de la Universitat Jaume I.

Davies, Florence. 1988. "Designing a writing syllabus in EAP: Process and product”. In Robinson P. C. (ed.), Academic Writing: Process and Product. ELT Documents 129. Birmingham: University of Birmingham, 121-131.

Dudley-Evans, Tony and Maggie Jo St John. 1998. Developments in ESP. A Multidisciplinary Approach. Cambridge: Cambridge University Press.

Ewer, Jack R. and E. Hughes-Davies. 1972. "Further notes on developing an English programme for students of Science and Technology". English Language Teaching 26/3, 269-273.

Fortanet, Inmaculada and Christine A. Räisänen (eds.). 2008. ESP in European Higher Education. Amsterdam/Philadelphia: John Benjamins.

Halliday, Michael A.K., Angus McIntosh and Peter Strevens. 1965. The Linguistic Sciences and Language Teaching. London: Longmans.

Herbert, Alfred J. 1965. The Structure of Technical English. London: Longman.

Jordan, Ron R. 1997. English for Academic Purposes. Cambridge: Cambridge University Press.

Johns, Ann M. and Tony Dudley-Evans. 1991. "English for Specific Purposes: International in scope, specific in purpose". TESOL Quarterly 25/2, 297-314.

Martínez, Iliana A. 2011. "Capitalizing on the advantages of the Latin American EAP situation: Using authentic and specific materials in EAP writing instruction". Ibérica 21, 31-48.

Monroy, Rafael. 1983. “Trayectoria y características de una nueva corriente en la enseñanza del inglés: el ESP”. Cuadernos de Filología. Teoría: Lenguajes 1/2, 143-160.

Munby, John. 1978. Communicative Syllabus Design. Cambridge: Cambridge University Press.

Nunan, David. 1989. Designing Tasks for the Communicative Classroom. Cambridge: Cambridge University Press.

Paltridge, Brian. 2009. “Afterword: where have we come from and where are we now?”. In Belcher D. (ed.), English for Specific Purposes in Theory and Practice. Ann Arbor: University of Michigan Press, 289-296.

Piqué, Jordi and David J. Viera. 1997. “Looking ahead”. In Piqué J. \& D. J. Viera (eds.), Applied Languages. Theory and Practice in ESP. Valencia: Universitat de Valencia, 11-15.

Robinson, Pauline C. 1980. ESP (English for Specific Purposes). Oxford: Pergamon Press.

Salager-Meyer, Françoise. 1999. “From 'Mr. Guthrie is profoundly mistaken...' to 'Our data do not seem to confirm the results of a previous study on...': A diachronic study of polemicity in academic writing (1810-1995)". Ibérica 1, 5-28.

Trimble, Louis. 1985. English for Science and Technology: A Discourse Approach. Cambridge: Cambridge University Press. 
Upton, Thomas A. 2012. “LSP at 50: Looking back, looking forward”. Ibérica 23, 9-28.

\section{NOTES}

1. In this paper, we will directly refer to ESP, and not LSP, even if other languages may also apply, for the concept of specialised languages; the reason is that, in agreement with Belcher (2009), ESP is generally the case in point when we deal with LSP diachronically.

2. For a detailed and thorough study of the influence of the Bologna process in other European Universities and the situation of ESP in these universities, see Fortanet and Räisänen (2008).

3. Many engineering Master programs demand a B2 (Council of Europe) language command for access, but the fact is that few students can comply with that requirement, so exams are being designed at a lower level, thus enabling students to register. Other ways to pass round the norms involve the presentation of some diplomas or certificates, e.g., from previous ESP courses at university or certificates from the language schools (although these procedures may also fail soon, as many technical degrees have removed ESP courses, and not all the students can have either the time, access, or money to enroll at language schools).

4. It is thus no surprise that the journal has gained great recognition with its insertion in the CIRC (Integrated Classification of Scientific Journals in Spain) as a level A journal and in the ERIH (European Reference Index for the Humanities) database as a NAT category journal on account of its many international database indexations. It also received a seal of excellence by the Spanish Ministry of Science and Technology in 2011, the only journal receiving it in the applied linguistics field. Some prestigious databases where it can be found include the Arts \& Humanities Citation Index, MLA International Bibliography, Social Sciences citation Index, etc.

5. For example, for volume 24 (2012), confirmed papers by Hyland, Tarp, Scott, Bernd Voss, and Salager-Meyer, among others, give a good indication of the journal's international projection.

\section{ABSTRACTS}

This paper aims to describe the development of English for Specific Purposes (ESP) as specialised language study and research at tertiary level in Spain over the past twenty years. The year 1992 is chosen as a starting point because AELFE, the Association of Languages for Specific Purposes, was founded in Madrid at the time. As more members from other countries have joined in, this Association has served as an academic landmark for the development of ESP within the umbrella of applied linguistics. ESP has reflected the social changes, educational shifts, linguistic trends, and technological innovations involved in academic and professional contexts. The evolution of the specialised language practitioner's scenarios and communicative situations has turned ESP into a lively and stimulating action, though not lacking in controversy, e.g., a general increase in the ESP teacher's workload. Different lines of work and research have been followed from the inception of AELFE until the implementation of the Bologna agreement in our universities. The examination of such variables is conducted in the light of some quantitative and qualitative findings.

Cet article a pour objectif de décrire l'évolution de l'anglais de spécialité (ASP) au sein des études en langues spécialisées et de la recherche au niveau de l'enseignement supérieur en Espagne au 
cours des vingt dernières années. L'année 1992 est choisie comme point de départ parce qu'AELFE, l'Association des langues à objectifs spécifiques, a été fondée à Madrid à cette date. Lorsque des membres d'autres pays ont rejoint cette association, AELFE a servi de point de repère institutionnel universitaire pour le développement de l'ASP dans le cadre de la linguistique appliquée. L'ASP reflète les évolutions sociales, les changements éducatifs et les tendances linguistiques, ainsi que les innovations technologiques au sein des contextes universitaires et professionnels. L'évolution des scénarios du praticien des langues spécialisées et des situations de communication a transformé l'ASP en une pratique vivante et stimulante, quoique parfois sujette à controverses comme, par exemple, à propos de l'augmentation générale de la charge de travail de l'enseignant d'ASP. Différentes directions de travail et de recherche ont été adoptées dans les universités espagnoles depuis la création d'AELFE jusqu'à l'accord de Bologne. L'examen de ces variables est effectué à la lumière de quelques résultats quantitatifs et qualitatifs.

\section{INDEX}

Keywords: AELFE, ESP, ESP research and teaching, Ibérica, Spain

Mots-clés: AELFE, anglais de spécialité, Espagne, Ibérica, recherche et enseignement en anglais de spécialité

\section{AUTHORS}

\section{GUADALUPE AGUADO DE CEA}

Guadalupe Aguado de Cea is a Senior Lecturer at Universidad Politécnica de Madrid. She is MSc in Translation by Universidad Complutense de Madrid (UCM) and she received her PhD in English Philology by UCM. Her current research activities include, among others: English for Specific Purposes, Terminology and Natural Language Processing, in which she has participated in different projects concerning terminology, ontologies and multilingualism. She is the President of the Committee on Terminology, AEN-CTN-191, AENOR, and the representative for Spain at the ISO TC 37. lupe@fi.upm.es

\section{ALEJANDRO CURADO FUENTES}

Alejandro Curado Fuentes is a Senior Lecturer at University of Extremadura, Spain. His teaching includes English for Specific Purposes (ESP) at the College of Business and Administration and Polytechnic School, as well as Applied Linguistics at the College of Humanities. His research focuses on corpus linguistics and ESP, as well as ICT and language learning. acurado@unex.es 